\title{
Anaxagoras on mind
}

\author{
Volume 8 Issue I - 2018
}

\author{
Stavros J Baloyannis \\ Research Institute for Alzheimer
}

\section{Keywords: Being, Mind, Neurophilosophy, Anaxagoras}

\section{Editorial}

Among the emerging theories on Mind of Pre-Socratic philosophers, the originality of Anaxagoras' concepts is particularly imposing. Anaxagoras' doctrine of the autonomous, infinite, powerful and eternal Mind, ${ }^{1}$ which is the purest of all things, the master of itself and the ruler on everything, controlling all the elements and directing all the physical interactions in the universe by the most proper way, ${ }^{2}$ is the most innovatory amazing theory in ancient philosophy. In addition, his ahead of the times subtle theory of the relationship between matter and energy, predicted in a prophetical way the revolutionary data of the modern science and philosophy. ${ }^{3}$

Anaxagoras' doctrine on the unique and eternal omnipotent

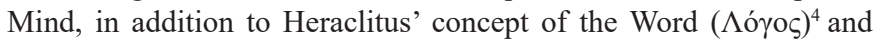
Parmenides' concept of Being (Eĩval $)^{5}$ exercised a crucial influence upon Platonic, Aristotelian and New-Platonic philosophies, lasting for centuries, surviving also in the modern philosophical streams as substantial theoretical links between philosophy, medicine and neuroscience. ${ }^{6}$

Anaxagoras was born in the city of Clazomenae in Asia Minor, during the seventh Olympiad (between 500-497 or 533 BC). He began to study philosophy at Athens in the archonship of Callias. Euripides, was his pupil and Pericles was a strong and precious friend. At the time of Socrates' birth, Anaxagoras was already in the fourth decade of his life, older than Empedocles. Socrates became acquainted with Anaxagoras doctrines attending lectures by Archelaos, an Anaxagoras' disciple. Diogenes Laërtius ${ }^{7}$ cited only one book written by Anaxagoras, which unfortunately, didn't survived, but only some excerpts of it lie embedded in the manuscripts of other writers, mostly in neo-Platonic Simplicius, Plutarch and Sextus Empiricus. ${ }^{8}$

The concept of Mind (Noṽ $)$ possess a dominant position in Anaxagoras' philosophical system. Everything is set and directed by Mind, which is the causative power of all creation. The Mind (Noṽs) is unique, original, eternal, authentic, autonomous, unlimited, unmixed with anything else, remaining pure and alone itself by itself, selfpowered, self-subsistent, self-sufficient, separated completely from all other elements. ${ }^{9}$ In addition, Mind (Noṽ $)$ is the finest and the purest of all things. It is free, infinite over time and space, stable, unchangeable, unique. The Mind (Noṽs) is also incorporated in the human being and acts as the leading power of the soul, ${ }^{10}$ which prevails over the body and configures its functionality fully, penetrating entirely the existence of all entities who are alive.

The mind, controls and directs properly all the mental functions, all the brain processes concerning both knowing and perceiving, the memory and the imagination, the emotions and the social behavior, the speech and the writing, the symbolic meanings and art, as well as the judgment and the creativity. In particular, Mind dominates on the inner life of the man, inducing peace, serenity and wisdom. ${ }^{11}$ However, because of the weakness of our senses we are not able to judge the truth always, ${ }^{12}$ since what appears obviously is only a partial vision of the unseen. ${ }^{13}$

\author{
Correspondence: Stavros J Baloyannis, MD, PhD, Professor \\ Emeritus, Aristotelia Univesity, Angelaki 5, Thessaloniki 5462I, \\ Greece., Tel 3023I0270434, Fax +302310434, \\ Email sibh844@otenet.gr
}

Received: January 01, 2018 | Published: January 04, 2018

From the Neurosciences' point of view, we may hypothesize

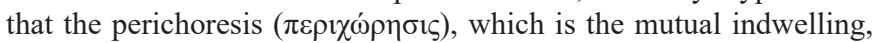
described by Anaxagoras may be related to continuous transport of neurotransmitters, proteins and organelles by the perpetual axoplasmic flow in the neurons and the neuronal processes, within the neuronal networks and tracts of the brain.

The Mind according to Anaxagoras is the unique steering power, which created Cosmos from the existing chaos, by triggering and initiating the rotation of the previously unmoved masses of various confused elements. Over time, the rotation throws lighter ingredients towards the edges of the perpetual whirl activity and pushes the heavier ones to the center. ${ }^{9}$ The velocity of the rotation is the highest possible rapidity, incomparable with any other similar phenomenon in nature. Thus, the Mind created all the celestial bodies, which are afterwards in a state of continuous movement inside the continuously expanding universe. ${ }^{9}$

Concerning the matter, Anaxagoras claimed that the matter may be divided and diminished endlessly, resulting in invisible elements, which may continue dividing. Accordingly, the division of the matter is infinite, in reality, inasmuch as each division leads unto immense number of further divisions. Thus, from each small element derives the smaller and further the even smaller, whereas the final absolute minimum never exists. The size of the material components affects only the ability to make them perceptible by the vision and the other senses. Consequently, Anaxagoras reasonably stated that we cannot know the number of the things that are separated off, either in word or deed. ${ }^{14} \mathrm{All}$ elements mixed together, compose the perceptible world, each item of which contains all the building units of matter. Therefore the elements of the matter become "homoiomerous", ${ }^{15}$ in spite of their eventual morphological and functional differentiation. The homoiomerous are divided constantly, never driven in the "nothingness" ${ }^{16}$ but they existed always together in an undifferentiated condition before the initiation of the procedure of the cosmogony. Surplus, the Mind gave the proper shape in all pre-existing and existing entities, constructing and configuring them harmoniously by its synthesizing capacity.

Although, in Anaxagoras philosophy, there is a clear distinction between mind and matter, in fact the Mind dominates upon the matter, 
activating all its properties and functionalizing it properly. The motion is the most obvious phenomenon of the changeability of all substances and the way of the transition from matter to energy. ${ }^{3}$ It is amazing that Anaxagoras' view on matter and cosmos was released many centuries before the theory of the nebula by Swedenborg, Kant and Laplace and the theory of cosmic reionization ${ }^{17}$ and the nucleosynthesis $(\mathrm{BBN}) .^{18}$

Anaxagoras' doctrines on Mind exercised a profound influence upon the philosophical orientation of the thinkers, who endeavored to discover the depths of the human soul in order to find the inner unseen links between soul and body and to enforce the expectation of the life in eternity, planning nevertheless the proper routs for the harmonious interpersonal interactions in the society. Concerning the Mind, Empedocles, whose central issue is the cosmic cycle of life, maintained that the soul is imperishable and Mind and Soul are essentially the same. ${ }^{19}$

According to Plato the human soul is immortal, ${ }^{19}$ invisible, unchanged and unchangeable and it is the most precious component of the human existence. The soul is the cause of life and expresses the true self of the human being, who has eternal self-identity. In addition, the human soul is characterized by cognitive function and intellectual properties and can regulate and control the body in all its functions and activities, although body and soul are essentially distinct. ${ }^{20}$ In the Republic, Plato introduced the tripartite notion of the soul. The Mind as searching for the truth, the logic, the moral and spiritual values, the ethics and the worths, as well as the pure knowledge and wisdom is evidently connected with the rational component of the soul, which would be the only proper place for the Mind. ${ }^{21}$

Plato agrees, after Anaxagoras, that the mind is possible to be the supreme leading power and the only creative cause in the world, which handles the elements and adjust the harmonic ratios in order to organize the universe, setting everything in order in the most perfect way. $^{22}$

According to Aristotelian philosophy, the Mind is closely connected with the Soul. ${ }^{23}$ As a matter of fact, the Mind is part of the rational component of the soul, which is the most functional part of the human entity, possessing an instrumental value for the life. ${ }^{24}$ The rational component is also the center of the cognition and judgment and it is reasonably considered as the most precious part of the human being. The Mind is also the divine element of the existence, which remains intact after death, unchangeable and immortal. ${ }^{25}$

The motion of the soul is basically the actualization of its potentiality. All the functions of the soul, including thinking, might be considered as "movements" of the soul. ${ }^{26}$ Cognition is the proper function of the rational component of the soul, ${ }^{27}$ since the sensitive soul is motivated mostly by the sensation, ${ }^{28}$ which is related with exterior sense-objects and accounts for all manifestations of life. Thinking is the expressed Act of Mind. Rational thinking leads to prudence, science and wisdom, as well as to insight, precise expression of thoughts and creativity.

Aristotle agrees, after Anaxagoras, that the Mind must be pure, integral, impassive and dominant. The Mind understands everything correctly, obtaining self-authorization and possessing his own dynamics. ${ }^{29}$ Aristotle, attempting to interpret the multidimensional character of Mind's activity, has introduced the consideration of the active and the passive Mind. The active and the passive mind collaborate continuously in order to allow discursive thinking and ethical behavior to emerge. The passive mind is perishable and the active is immortal and eternal. Thus the active mind could exist in the absence of the passive. ${ }^{30}$
The Aristotelian concept of passive Mind, which is perishable, temporal and closely related with corporal activities corresponds clearly to mental functions of the brain, which are based on multiple cortical and subcortical processes, that are related with consciousness, perception of the senso-sensorial informations, memory, imagination, emotions, behavior, learning, judgment, creativity, rational, symbolic and constructive thinking, development of verbal and written communication, of arts and music and mainly with the development of interior life. ${ }^{31}$

Plotinus, in contrast to Anaxagoras, declared that the supreme principle in the world is the One, who is the only primary authority with creative properties. The One is the absolute prime principle of all, which is greater than the being and the thinking, since the Being is involved in the continuous struggle between soul and flesh.

The One is entirely simple and expresses the absolute Beauty and the supreme Goodness (vं $\varepsilon \varepsilon \rho \alpha \gamma \alpha \theta 0 v){ }^{32}$ The internal activity of the One is its own hyper-intellectual existence. Its external activity is expressed by the activity of Mind. The quality of life is the life of the Intellect. One of the properties of the intellectual and really happy life is its self-sufficiency, which is based on the cognitive identification with all that are intelligible and longing for the Good.

Plotinus proclaims the eventual victory of the spirit over the carnal body of the human being. The human being is essentially a soul employing a body, as an active instrument of its terrestrial temporal life. A person can behave by acting solely intellectually and the soul may be elevated to spiritual world, towards the absolute Goodness, escaping from the tragic narrow cage of the perishable body. ${ }^{33,34}$

In the contemporal existential philosophy, according to Kierkegaard, the human being is an existing infinite Spirit ${ }^{35}$ and Mind. Thinking and understanding, may have either an aesthetic-intellectual character or an ethico-religious one, depending on the intelligence, wisdom, spiritual culture and elevation of the individual. ${ }^{36,37}$

In conclusion, Anaxagoras is among the greatest philosophers of the world, who introduced the Mind as the supreme, infinite, dominant, autonomous, authentic creative power, who constructed the universe by multidimensional synthesis of the matter by "homoiomerous" elements, that may be divided immensely and infinitively, never ending. He recognized the velocity as the main factor of transition from matter to energy. Anaxagoras theories and hypothesis carry the prophetic message of the contemporary conclusions of the astrophysics, bonding also harmoniously philosophy with science.

\section{Acknowledgments}

None.

\section{Conflicts of interest}

None.

\section{References}

1. Kirk GS, Raven JE, Schofield M. The Presocratic Philosophers: A Critical History with a Selection of Texts. ( $2^{\text {nd }}$ edn), Cambridge, UK. 1983;pp.501.

2. Grujić P. The Concept of Fractal Cosmos: I. Anaxagoras ' Cosmology. Serb Astron J. 2002;163:45-65.

3. Gershenson D E, Greenberg DA. Anaxagoras and the Birth of Physics (A History of Physics: its Concepts, Methods and Theories. Series I: Natural Philosophy before Aristotle). Introduction par Ernest Nagel, Blaisdell, New York, USA. 1964. 
4. Baloyannis SJ. The philosophy of Heraclitus today. Encephalos. 2013;50:1-21.

5. Baloyannis SJ. The message of Parmenides in the era of globalization. Encephalos. 2004;41:71-78.

6. Baloyannis SJ. Galen and the Neurosciences. J Neurol \& Stroke. 2016;4(1):00116.

7. Laërtius, Diogenes. Lives and Opinions of Eminent Philosophers In: Yonge, Charles Duke, et al. (Eds.), (1972) Lives of Eminen Philosophers. Diogenes Laertius. RD Hicks. Harvard University Press, Cambridge, London, UK.1853.

8. Baloyannis SJ. Sextus Empiricus and the modern medical philosophy Encephalos. 2013;50:62-74.

9. Fragments of Anaxagoras . Translated by John Burnet, Fragm.12, 1920

10. Aristotle De anima i. 19; 405 b 19.

11. Baloyannis SJ. Being and Mind. J Neurol \& Stroke. 2016;5(1):00167.

12. Fragments of Anaxagoras. Translated by John Burnet, Fragm.21. 1920.

13. Fragments of Anaxagoras. Translated by John Burnet, Fragm.21a. 1920.

14. Fragments of Anaxagoras. Translated by John Burnet, Fragm.7. 1920.

15. Leon P. The Homoiomeries of Anaxagoras, The Classical Quarterly, XXI, p. 138. 1927.

16. Sartre JP. Being and Nothingness. A Phenomenological Essay on Ontology. Washington Square Press, Pocket Books, New York, USA. 1966.

17. Robertson BE, Ellis RS, Furlanetto SR, et al. Cosmic reionization and early star-forming galaxies: a joint analysis of new constraints from Planck and the Hubble space telescope. Astrophys J. 2015;802:19.

18. Richard H Cyburt BD, Fields KA, Olive Tsung-Han Yeh. Big bang nucleosynthesis: Present status. Rev Mod Phys. 2016;88:015004.

19. Baloyannis SJ. Empedocles and the Neurosciences. Encephalos. 2014;51:68-80.
20. Plato. Republic 608 d. and II, $381 \mathrm{~b}$.

21. Plato Phaedo 64c4-8.

22. Giannakopoulou Maria. Plato on soul and body. PhD thesis, University of Glasgow, UK. 2002.

23. Plato Phaedo 97 d. and Kratyl. 413 C.

24. Aristotle Meta i 4; 985 a 18.

25. Aristotle De Anima III, 4, 429 a 22-24.

26. Aristotle De Anima III, 4, 429 a 10-13.

27. Aristotle De Anima. III. V, 430a 22-23.

28. Descartes R. Meditations on First Philosophy. Edited Stanley Tweyman. Routledge, London and New York, USA. 1993.

29. Aristotle. De Anima III. III, 427 b 8.

30. Aristotle De Anima 425 b 12.

31. Aristotle De Anima III. IV, $429^{\mathrm{a}}$.

32. Brentano Franz. The Psychology of Aristotle (in particular his doctrine of the active intellect). Translated by George Rolf Berkeley, University of California Press, USA. 1977.

33. Plotinus. In 7 volumes, Greek text with English translation by $\mathrm{AH}$ Armstrong. MA Loeb Classical Library, Cambridge, UK. 1968.

34. Davarinou PG. Plotinus'attempts to go beyond the Platonic philosophy. Thesis, Athens, Greece. 1995.

35. Kierkegaard S. Søren Kierkegaard's Journals and Papers. (Vol 4), In: Howard V Hong, Edna H Hong, Indiana University Press, Indiana, USA. 1976.

36. Kierkegaard Søren, Vincent HH, Hong E. Philosophical Fragments and Johannes Climacus. Princeton University Press, Princeton, USA. 1985.

37. Baloyannis SJ. The philosophy of the solitude. Encephalos. 2015;52:14-24. 